ARTICLE

Received 7 Sep 2016 | Accepted 14 Feb 2017 | Published 14 Mar 2017

DOl: $10.1057 /$ palcomms.2017.16

\title{
Toward quantifying soft power: the impact of the proliferation of information technology on governance in the Middle East
}

Nikolay Anguelov ${ }^{1}$ and Tiffany Kaschel ${ }^{1}$

\begin{abstract}
This study examines how information technology and mass communication outlets have been employed as soft power platforms in the Middle East in the aftermath of $9 / 11 / 2001$. The focus is on Internet access and mobile phone subscriptions to see how their proliferation has impacted government effectiveness and political stability in MENA nations from 2004 to 2014. The analysis is centred in the context of increased American investment in soft power programs in the region with the goal of reducing instability and anti-Western sentiments. We examine the nature of such investment in relation to information technology dependence. Understanding that the necessary technology is a product of Western-centric multinationals, we study the interplay between imports, foreign aid and foreign direct investment (FDI), as direct metrics of foreign capital intensity and our explanatory variables - Internet and mobile technology usage rates. The results suggest that information technology platforms contribute to improved governance, while foreign aid has a negative impact. We further examine if increased government effectiveness and stability attracted FDI, as a representation for a positive outcome of improved governance, and find that such governmental efficacy was a successful predictor of foreign direct investment growth, while political stability was not. This article is published as part of a collection on soft power.
\end{abstract}

\footnotetext{
${ }^{1}$ University of Massachusetts, Dartmouth, MA, USA Correspondence: (e-mail: nanguelov@umassd.edu)
} 


\section{Introduction}

or decades the relationship between the American and Middle Eastern governments has been strained and often complicated (Tillman, 1982; McAlister, 2005; Little, 2008). In a post 9/11/2001 world, following the inconclusive campaigns in both Iraq and Afghanistan, war weary Americans are increasingly opposed to military action in the region. Verčič (2008) posits that as the costs of aggression and coercion grow, soft power becomes a desirable alternative in conflict resolution. Soft power refers to reliance on the charismatic allure of culture, emphasizing shared values and other persuasive modes of appeal to induce beneficial exchanges that reduce enmity (Nye, 1990). Such persuasive modes of appeal are subject to transmission. In that context, this research tracks how American soft power initiatives have been deployed in the Middle East with the proliferation of recent information technology innovations.

The Middle East does not have a definitive geographic or political area (Davison, 1960). For our purposes, we select a sample of 20 nations in the Middle East, southwest Asia and northeast Africa because of their strategic importance to American regional interests. They are: Afghanistan, Algeria, Bahrain, Djibouti, Egypt, Iran, Iraq, Jordan, Kuwait, Lebanon, Oman, Pakistan, Qatar, Saudi Arabia, Syria, Tunisia, Turkey, United Arab Emirates, West Bank/Gaza and Yemen. Our sample is derived from literatures on American-Middle East contentions that examine instances of conflict mitigation through public diplomacy and soft power tools. The review of those bodies of literature points us to digital divide issues and therefore, we examine how the proliferation of information technology has impacted regional soft power programs.

We identify Internet usage and mobile phone subscription as technological platforms of interest. They serve as our explanatory variables and we test whether their growth in the region post 9/11/ 2001 has had an impact on metrics of improved governance. As Pamment (2015: 203) explains, media channels are "enablers" and "meeting places" of idea exchange. Kroenig et al. (2010) maintain that soft power implementation will be more successful in an environment with a functioning marketplace of ideas. We focus our query on the connection between "meeting places" and "functioning marketplaces" of ideas. We link the two concepts and provide a basic information technology market dynamics analysis. Showing that information technology is largely imported by Middle Eastern nations, we look at the channels for its acquisition by including imports, foreign direct investment (FDI) and net official development assistance (ODA) as control variables. Our goal is to offer an example of an empirical model with variables that can be proxies for vehicles of soft power. For instance, Internet and mobile phone usage not only improve and increase communication among citizens, but also carry in foreign cultural and political messages. Foreign aid, FDI, and imports may serve as a conduit for such ideas, frequently by way of introducing, exhibiting and promoting international products and behaviour (Miller and Thorr, 2003; Hayden, 2012; Jiang and Wei, 2012).

With foreign assets come foreign products, foreign marketing, foreign managerial practices and behaviour, and foreign ideas. Therefore, such venues of external information have ideological and political sides. Ideologically, as other researchers have shown, marketing and advertising impact image perception. Politically, such idea exchange can affect mobilization and create pressure for positive change in governance. Therefore, our main hypothesis is that the growth of these channels of soft power messages transmission will have an impact on governance. As proxies for government responsiveness, we employ The World Bank Worldwide Governance Indicators (WGI) metrics of government effectiveness and political stability and absence of violence and terrorism. Our results suggest that digital connectivity, the importation of new products, and FDI lead to improvements in government effectiveness but this contribution does not necessarily improve political stability. We offer a discussion as to why. The results also point to a negative relationship between foreign aid and governance performance, supporting prior research that cautions against aid dependence.

\section{Soft power overview}

The soft power literature is an assortment of approaches and opinions about the concept, its effectiveness and its impact. Some scholars have attempted to do so qualitatively via interviews and polls (Nisbet et al., 2004; El-Nawawy, 2006; Rugh, 2006), others have relied on more quantitative methods (Knack, 2004; Smith, 2007; Atkinson, 2010; Golan and Yang, 2013). Some examples include assessments of government programs (DoS ECA, 2009), others analyze survey results taken by think tanks such as Zogby International.

The challenge faced by researchers is the ambiguity of soft power. Its measurement is often reduced to gauging resources or looking at soft power through a lens of case-based assessments of a circumstantial situation, which Hayden (2012) argues, is not representative of the way soft power translates into policy outcomes. For example, in a post 9/11/2001 world one of the goals of U.S. soft power is to reduce the threat of terrorism. Any scholarly attempt to quantify such a "reduction" would be idiosyncratic. Perhaps this challenge is why the interdisciplinary literature on soft power finds limited benefits. And yet, the concept is growing in importance; it has proliferated political parlance and in the current political climate, the term has become a cornerstone in discussions on international diplomacy.

Because of this international proliferation, Yun and Kim (2008) examine soft power in a global context looking at how ethnic links, reputation and formal relationships with other nations can build a country's soft power. The authors find a significant relationship between ethnic linkage and soft power that is preceded by reputation. When the main ethnic group in a nation holds a negative view of another nation, soft power tactics are unsuccessful even when the nations are ethnically linked. In relation to the importance of reputation, Fan (2008) explains that soft power effectiveness is determined by the perception of the population in the target country and therefore, soft power policies and initiatives must be tailored to ethnic, religious and cultural preferences of targeted populations.

It is harder to answer the question of which segments of targeted populations respond better to soft power. In such an attempt, Goldsmith and Horiuchi (2012) analyze 58 multinational surveys linking soft power and public perception of American foreign policy. The authors find that public opinion of U.S. foreign policy influences local leaders' foreign policy decision-making. The implication is that soft power can create a bottom-up effect as it can influence governments indirectly by the effects it can have on general populations. Our study tracks the main ways through which such bottom-up effect can be created. One of the most discussed ways is through education.

America, in particular, uses formal education as official diplomacy by deploying a variety of exchange programs through both public and private organizations. Studying their soft power efficacy, Atkinson (2010) finds that increasing participation in educational exchanges leads to altering negative perceptions of America in the recipient country and this change can be linked to improvements in local human right records. This is a very optimistic conclusion and Snow (2008) points out that to understand it better there must be quantitative research on what factors during the exchange studies experiences led to the change 
of views about America. Specific to the Middle East, Rugh (2006) provides such examples in 10 stories that include Fulbright exchanges and youth retreats.

A more quantitative body of research on soft power has addressed the relevence of foreign aid as a direct monetary metric of investment in building good will. The results are mixed. Some authors caution against over-optimistic faith in aid and argue that it may lead to dependence with little impact on diplomatic, democratic, and quality of life improvements. For example, Knack (2004) examines aid's impact on various democracy indices while controlling for GDP, income, illiteracy, and infant mortality rates and finds aid to have been mostly ineffective. Bjørnskov (2010) explains that this is because often local elites are able to simply appropriate aid funds. The author argues that it is not the amount of aid, but the accountability structures around its disbursement that matter. In relation, Smith (2007) shows a link between deteriorating American diplomatic action that impacts foreign aid and increasing local anti-Americanism.

Yet, some scholars offer evidence of aid benefits. Savun and Tirone (2011) find it essential in preventing civil conflict and strengthening democracy. Van de Walle (2012) offers such an example from Mali, where foreign aid is credited with strengthening accountability measures critical for building democracy. Scott and Steele (2011) observe a significant positive relationship between specific democracy aid packages and improvements in democratic records.

Much like Knack (2004) and Smith (2007), Nye (2008) discounts the use of money as an effective tool of soft power. He asserts soft power cannot be measured in dollars; it can only be measured in the number of changed minds. Therefore, it is imperative to understand the target audience's thoughts, values and desires. But would such an understanding of changed minds, as Nye puts it, lead to significant pressures on local governments to improve policies? For this study's region of interest, the aid and soft power efforts to strengthen democracy result from the fact that the local MENA governments are, at large, undemocratic. Given these circumstances, it is unclear whether understanding the change in popular opinion, as Nye prescribes, is the path for analyzing the policy effectiveness of soft power initiatives. As we see in the case of present day Syria, after 6 years of protest, reflecting change in the hearts and minds of people, local government is unyielding.

Smith (2007) points out that it is a combination of factors that shape public opinion about a foreign country, including specific foreign policy, official diplomatic action, soft power, and individual citizen interactions. The author argues that the strongest factor is official foreign policy. According to Smith's reasoning, if people believe that U.S. policies are against them and their national interests, they will remain soft power resistant. The issue still lies in representation with respect to how well local government actions reflect their peoples' beliefs. In the Middle East it is this dichotomy that has contributed to the growing investment in soft power programs.

\section{American soft power in the middle East}

The U.S. State Department's Executive Budget Summary for FY $2014^{1}$ reveals the U.S. government spends millions of dollars in various soft power programs abroad, ranging from televised and radio broadcasts, to multitudes of online communication platforms, to exchange student programs. Although not specifically stated by the State Department, scholars examining the effectiveness of such programs posit that they are deployed for the general purpose of perpetuating favourable opinions towards America, the American public, and U.S. policies abroad (Nye, 1990, 2002, 2004, 2008, 2010; Atkinson, 2010; Hayden, 2012).
Several such programs, most notably the Middle East Partnership Initiative (http://mepi.state.gov/about-us.html) and Radio Sawa, have been deployed specifically to the Middle East post 9/11/2001 in an attempt to address ideological differences (http://www. radiosawa.com/info/radio_sawa/108.html). Program deployment follows the established American practice of using media, particularly easily transmittable radio signals, to share its message (Puddington, 2003). ${ }^{2}$ A government sponsored initiative of the Broadcasting Board of Governors and funded by Congress, Radio Sawa (meaning "together" in Arabic) attempts to improve the image of America by promoting the best of its popular culture (Schneider, 2003). The station deliberately alternates newscasts broadcasted in local languages with contemporary Arabic and Western music. Schneider (2003) explains that the strength of its programming is in illustrating free speech by reporting objectively and offering both positive and negative stories about America. To gauge the effectiveness of this strategy, ML El-Nawawy (2006) asked students in 5 Arab countries if they thought Radio Sawa, and a similar media organization, Television Alhurra, to be trustworthy news sources. The author explains that respondents who had listened to Radio Sawa had a poorer opinion of the U.S and its foreign policy, in part because they believed the broadcasts to be manipulative. ElNawawy does not find a significant link between the frequency with which one listened to Radio Sawa and positive opinions of America and its foreign policy. The study reports a positive relationship between Television Alhurra's credibility and U.S. foreign policy favorability, however no discussion is offered as to why that may be. That result may reflect the general findings from the communication's literature on the power of television images (Allen, 2015; De Mooij, 2013; Elasmar, 2014) which argues that television, music videos and film are stronger persuaders than radio and news print because of visual absorption. ${ }^{3}$ From those works, the one most directly related to the Middle East is Fullerton and Kendrick's (2006) description of the short-lived and controversial Shared Value's Initiative (SVI). ${ }^{4}$ SVI's main tactic was to televise commercials in Muslim-majority countries of the happy lives of Muslims in America. The authors surveyed 500 students from 39 countries and found that the commercials did in fact improve attitudes toward America.

Just like Fullerton and Kendrick's (2006) methodology, the communications literature on image perception is largely based on polling, surveys and interviews. Our focus here is on soft power methodology and to that effect, we heed Melissen and Lee's (2011) caveat that polling data has many limitations as it is prone to subjectivity, selection bias and framing. This warning, in light of El-Nawawy's findings on manipulation awareness and related works by Kamalipour and Snow (2004) and Taylor (1992) on distrust of soft power media sources that are believed to be created as tools of propaganda, is notable because the soft power literature, at large, is based on polling, surveys and interviews.

However, if we adhere to Nye's (1990) definition that soft power is about changing hearts and minds, the most direct way to study such change would indeed be in the form of polls and interviews. In June 2004, as a follow-up to a 2002 study, "Impressions of America", the Arab American Institute commissioned Zogby International (a polling arm of Zogby Analytics (http://www.zogbyanalytics.com/about-us)) to survey almost 3,300 Arabs living in Morocco, Saudi Arabia, Jordan, Lebanon, the United Arab Emirates and Egypt. The questions asked how Arabs view America, as well as how Arabs learn about America and its culture. ${ }^{5}$ The findings suggest that, except in Jordan, watching American programming led to improving views of the United States. The relationship is particularly strong in Saudi Arabia where respondents rank the positive influence of watching American television as stronger even than knowing Americans or 
having been to the United States. However, the results also indicate that all of this favorability does not change negative opinions about American foreign policy. Those respondents that had visited the U.S. gave a favourable rating of the country, its values (including democracy), American products and the American people. Those who have personally known Americans but had not visited the United States also offered higher favorability rating of the United States, (with the exception of Jordan, where the study did not find an impact either way) although not to the same degree as those who had travelled to America. Again, this favorability did not extend to foreign policy.

In his own assessment of the Zogby survey findings, Jreisat (2006) explains that the Zogby results mainly indicate that Arabs and Muslims dislike American policies, which they feel are largely biased against them. They do not generally disapprove of the American way of life, freedom or democracy. The implication is that a negative legacy of American foreign policy cannot simply be moderated by seductive images of happy, luxurious living. When examining the impact of a change of such legacy, Golan and Yang (2013) focus on the influence of the American president. Using data from a 25-Nation Survey conducted for the Pew Research Center's Global Attitudes Project ${ }^{6}$, the authors find that President Barack Obama's now famous gesture to reach out to the Middle East in his 2009 Cairo speech was the beginning of a major change in policy direction that has improved local citizens' views of America. A related project by Nisbet et al. (2004) surveying non-Muslim citizens in predominantly Muslim countries found that regardless of personal religious affiliation, the respondents had an anti-American "perceptual screen", only acknowledging messages that fit within their preconceived notions. The results suggest that people were selecting U.S.sponsored programs aligned with their personal ideological positions while dismissing those stressing ideas not fitting their "perceptual screens". Because of this finding, the authors question the benefit of deploying diplomatic media programs.

The richest source of primary data on the subject is by far the Pew Research Center's Global Attitudes Project. It has conducted over 330, 000 interviews in 60 countries in the thirteen years since its inception. With respect to soft power, its $2012^{7}$ survey found that even in Arab nations where opinions of the United States remain fairly poor, certain outcomes of American "soft power" such as regard for business, popular culture, science and technology, increased in popularity during the Obama administration. The increased approval of American popular culture and even general ideas about American-style democracy were strongest among those age 30 and under. This is a very important and encouraging finding because more than half of the population in the Middle East is under 30. Assaad and RoudiFahimi (2007) describe this demographic change as a "youth bulge". But even among the young, the report notes a fear of American ideals overtaking local culture. In 17 out of the 20 surveyed nations, respondents expressed disapproval of the proliferation of American ideas and customs in their homelands.

Given the more positive outlook of Middle Eastern youth toward the United States, the American government has increased investment in exchange student programs. The Bureau of Educational and Cultural Affairs (ECA), part of the United States Department of State, is responsible for U.S. sponsored exchange programs and within the ECA, the Office of Policy and Evaluation assesses program effectiveness. Specific to the Middle East, the Youth and Exchange Study (YES) program ${ }^{8}$ was established post $9 / 11 / 2001$ for high school students from predominantly Muslim countries. The evaluation of the YES program indicates that participants acquired a better understanding of both America and their own countries. Students exhibited improved leadership skills and a sense of personal empowerment. Some also became advocates for greater cultural tolerance and respect of individuals' rights. We must note here that these findings may be biased, as the evaluation is internal to the YES program. However, they are worth noting because of the discussion of a major limitation with cultural implications for soft power. The strong positive effect of the experience had worn off "slightly" after students becoming reacclimated to their social circles back home. What constitutes "slightly" is unclear, although the finding is contributive in showing that exchange students are susceptible to local antiAmerican rhetoric, even after a year-long, very positive stay in the United States.

Anecdotal evidence of soft power effectiveness has also been recorded in case-study format. Most cited is the work of Rugh (2006), who offers ten "practical" examples. Using testimonies, interviews and other qualitative measures, Rugh illustrates that each method can be used as a valuable tool to assess soft power effectiveness. This is the approach that the World Bank utilizes when creating the variables in their WGI Project. The project draws on four different types of data sources to compile scale metrics for grading government performance. ${ }^{9}$ We employ the metrics offered in a model to offer a quantifiable way in measuring soft power's impact on government effectiveness in the Middle East.

The body of work on soft power illustrates there is no one right way to quantify it, as there is no one form of soft power. As the literature examined here shows, previous attempts to quantify its impact show effective, ineffective, and even counterproductive results. However, does that mean the concept is unquantifiable? We posit that it is quantifiable through a benefit-cost approach.

Soft power is a product of investment whether we speak of cultural exchanges, study abroad programs or media content. All are subject to funds, the decision to increase or decrease such funds, and the choice of how to most effectively direct the product of such investment. In Anguelov (2015), we built a model focusing on macro-level government action in combination with metrics that we use as proxies for openness to foreign information, which include investment, imports, and foreign aid. We posit they can be viewed as channels through which soft power ideas can not only be disseminated, but also managed. Their deployment is subject to benefit-cost analysis. In the soft power literature few studies, such as Bussee and Hefeker $(2007)^{10}$ as well as Chan and Gemayel (2004), examine investment in such soft power vehicles. However, their datasets do not reflect the impact of current innovations in telecommunication technology and digital connectivity.

\section{Data and methods}

We follow up on our previous model from Anguelov (2015) by offering the following changes. First, we extend the time series. Second, we change the focus toward telecommunication investment and proliferation with a particular attention on imports as the most current data from the region shows that the technologies and necessary hard and software are imported. We examine this trade dynamic in some detail in the analysis section. Third, we use a different measure of imports provided by Observatory of Economic Complexity's Media Lab at the Massachusetts Institute of Technology. In Anguelov (2015), we employed imports as percent of GDP; in this article, we use import amounts in billions of current U.S. dollars. Fourth, for the purpose of focus, we omit the female/male ratio in secondary schools from the model used in Anguelov (2015). ${ }^{11}$ The main variables we employ still are:

(1) Government Effectiveness-defined by the World Bank as "perceptions of the quality of public services, the quality of the civil service and the degree of its independence from political 
pressures, the quality of policy formulation and implementation, and the credibility of the government's commitment to such policies." ${ }^{2}$ The choice stems from Nye's (2004) explanation that soft power is the skill to affect government behaviour. We use the scores as proxies of responsiveness to soft power. Kroenig et al. (2010) explain that soft power implementation is successful in an environment with a functioning marketplace of ideas. The literatures on governance in transitional societies links market failure to soft power effectiveness and explains that this "functioning marketplace of ideas", to use Kroening et al.'s words, occurs as a result of formal market improvements. Evidence shows that government effectiveness can be linked to improvement in policies due to diplomatic engagement with end results that range from higher per capita income and literacy rates to a growth in prosperity, security and economic stability (Kaufmann et al., 1999; Brown et al., 2008; Lee and Whitford, 2009). Therefore, in this model we look at soft power in relation to economic indicator change. To that effect we must control for stability in markets and society because security and economic prosperity are linked. That's why our next variable is a political stability index.

(2) Political stability and absence of violence and terrorism "capturing perceptions of the likelihood that the government will be destabilized or overthrown by unconstitutional or violent means, including politically-motivated violence and terrorism."13 Because this definition is terrorism contingent (we later try to granulate why), we justify our choice with the words of Wunderle and Briere (2007) who argue terrorism is most effectively countered by policies based on soft power tactics that increase investment in education as well as free market structures. In our sample of nations during the 10 years in focus the causes of terrorism are diverse and to analyze them would be beyond the scope of this study. However, economic hardship and disenfranchisement do come up in studies such as Tujean et al. (2004) and Takeyh and Gvosdev (2002).

We employ these two variables as both dependent and independent to evaluate their fit as predictors and outcomes of soft power. The World Bank offers very little direct explanation on how the actual index numbers are derived, except that they are a result of primary research such as surveys and polls - the main methodology in the extent soft power literature. The question is would the newly created scores be useful when trying to quantify soft power transmission in the context of more direct metrics. We argue that such metrics are our two main explanatory variables:

(3) Internet usage (per 100 people)-people with access to the worldwide web (http://data.worldbank.org/indicator/IT.NET. USER.P2?display = default).

(4) Mobile phone subscriptions (per 100 people)-subscriptions to a public mobile telephone service using cellular technology. Post-paid and prepaid subscriptions are included (http://data.worldbank.org/indicator/IT.CEL.SETS.P2?display = default).

We select these variables based on the information technology literature that looks at adoption rates in our region of interest. As Agar (2013) explains, both direct and transaction costs of mobile service dissemination are much lower than those of increasing landline connectivity. Aker and Mbiti (2010) explain that the lower cost associated with mobile phone usage have facilitated the rapid transmission of economic, social and political information not only because of more possibilities to access external news and popular culture sources, but also because of the opportunity to engage in social media platforms. It is expected that through such engagement social knowledge is built and, as Mattern (2005) posits, soft power is communicating social knowledge. Pertaining to our research, there is evidence that protesters in the Egyptian uprisings of 2011 organized by communicating primarily via mobile phones (Khamis and Vaughn, 2011; Dunn, 2011). Newsom and Lengel (2012), who study Arab feminine cyber activism, explain that social media utilized via both the Internet and smart phones was the main vehicle of political mobilization during the Arab spring. In addition, modern telecommunication technology may facilitate communication between citizens and their governments which may affect government responsiveness. Roselle et al. (2014: 80) succinctly state: "connectivity creates new distributions of power".

Technology is not free. It is a product of innovation that is external to our region of interest. It arrives in MENA nations via channels of international commerce. Therefore, our model includes the most often used metrics of trade openness to examine how trade volumes inter-relate to technological proliferation of soft power platforms. We control for:

(5) Gross National Income (GNI) per capita (formerly GNP per capita) - "the sum of value added by all resident producers plus any product taxes (less subsidies) not included in the valuation of output plus net receipts of primary income (compensation of employees and property income) from abroad, divided by midyear population." (http://data.worldbank.org/ indicator/NY.GNP.PCAP.CD?display = default) Seminally, Nincic and Russett (1979) find that rising GNI improves both governance and economic growth. In relation to our main dependent variables-government effectiveness and political stability-Husted (1999) notes a significant correlation between low GNP (aka, GNI) and the corruption in a country, resulting in instability and inequality. For our query, GNI is of particular interest because it is a proxy for the purchasing power of the general population and therefore, the commercial viability of technological adoption. We are interested in the relationship between changes in personal wealth, IT proliferation, soft power deployment, and improvements in governance. Technological proliferation in the region is a direct product of foreign capital so our next proxy for trade and soft power openness is aggregate foreign direct investment.

(6) FDI-the combination of equity capital, reinvestment of earnings, other long-term capital, and short-term capital as shown in the balance of payments (http://data.worldbank.org/ indicator/BX.KLT.DINV.WD.GD.ZS). The impact of FDI on governance has been well noted by the literatures on international political economy, economic geography, and business management. Findings particularly relevant to our query look at the positive relationship between improved governance and FDI inflows as an economic growth strategy broadly termed industrial recruitment (Kaufmann, Kraay and Zoido-Lobatón, 1999; Globerman and Shapiro, 2002). Specific to our model is the work of Blanton and Blanton (2007) who posit that political stability is the core attractor of FDI. In terms of soft power, Luo and Tung (2007) explain that FDI brings new products into a nation and often those products are advertised by promoting foreign lifestyles. On the basis of that argument, we examine FDI as both a cause and an effect of soft power.

Foreign products and ideas do not always penetrate as a result of direct foreign investments but particularly in less liberalized economies (which we have in our model), are imported. Therefore, we also control for imports.

(7) Imports in billions of current U.S. dollars-the value of all goods and other market services received from the rest of the world. They include the value of merchandise, freight, insurance, transport, travel, royalties, licence fees and other services, such as communication, construction, financial, information, business, personal and government services. It is in the concepts of these services where we posit soft power lies (https://www.media.mit. edu/projects/oec-new/overview/). Miller and Thorr (2003) show that imported products largely use marketing campaigns from 
their countries of origin. When showcasing lifestyle benefits, those campaigns may promote messages of political nature. Additional evidence of the impact of imports on improvements in local welfare comes from Ahmed, Cheng and Messinis (2011) who show that import growth causes FDI as well as GNI growth.

Our last proxy for a vehicle of soft power is the often-discussed foreign aid. The literature on aid's impact on governance is one of the most voluminous, spanning several disciplines that study development and global governance. What makes it unique is that, unlike other metrics of foreign capital, it comes from public entities, not private sources. Governments use it to build good will (Lam, 2007; Radelet, 2003). To that effect, its deployment has been much studied as a diplomatic tool. In terms of soft power, Pamment (2015) boldly states that foreign aid is used by the U.S. government to spread American values.

(8) ODA and Foreign Aid-disbursements of loans made on concessional terms (net of repayments of principal) and grants by official agencies of the members of the Development Assistance Committee (DAC), by multilateral institutions, and by non-DAC countries to promote economic development and welfare in countries and territories in the DAC list of ODA recipients (http://data.worldbank.org/indicator/DT.ODA.ALLD.CD).

Since our explanatory variables are vested in technological innovation, we focus on a time frame when this innovation reached viable levels to deployment and proliferation in the MENA region. We start with the most current year for which data are available, which is 2014 , and count back to a time when mobile technology appeared and began to spread. For that reason our range is 2004-2014. This time frame allows us to examine the effect of soft power during the Iraqi insurgency, Egyptian uprising, and the on-going conflict in Syria. ${ }^{14}$ All metrics, except for import data, come from the World Bank, both from its yearly data tables and from the WGI Project. For those instances in which data points were missing, these other sources were used to fill the gaps and create a more comprehensive set. ${ }^{15}$ Imports come from The Observatory of Economic Complexity at the Massachusetts Institute of Technology. ${ }^{16}$

\section{Findings and analysis}

As per Baltagi (2008) and Greene (2008), we perform a Hauseman test on each panel to determine if a fixed or random effects approach is best suited to the particular combination of variables. The results indicate the need for fixed effects tests in all three panels. ${ }^{17}$ In the first regression we employ the government effectiveness score as the dependent variable. The findings are in Table 1 below.

To control for endogeneity when using political stability as an explanatory variable, we lag it by one year. This approach cannot fully control for a possible circular relationship. Our query and interpretations aim to offer examples of how the score developed by the World Bank can be used as indicators when studying relationships, rather than establish causal, directional links in those relationships. When it comes to concepts such as political stability and government effectiveness, their subjective nature would always challenge positions on which predicated the other.

Endogeneity can also be a factor with respect to FDI. In general, most researchers have looked at FDI as an outcome of good governance (Globerman and Shapiro; 2002, 2003; Wint and Williams, 2002; Gani, 2007). However, we posit that in regions such as MENA, comprised of economies increasingly dependent on FDI (Daniele and Marani, 2006) and vying for its annual increase, there is a propensity for local governments to compete for FDI by improving policies. It may be unclear whether it is an increase in government effectiveness that attracts foreign investors, or whether the foreign firms bring with them

\section{Table 1 | Fixed effects cross sectional time series regression} analysis, government effectiveness, 2004-2014

\begin{tabular}{llll} 
Variables & Coefficient & Standard Error & Significance \\
\hline $\begin{array}{l}\text { Internet Subscribers } \\
\text { (per 100) }\end{array}$ & .005842 & .0014339 & $\star \star \star \star$ \\
Mobile Subscribers & -.0016293 & .0007852 & $\star$ \\
(per 100) & & & \\
Imports & .0031536 & .0007597 & $\star \star \star$ \\
FDI & $6.83 e-12$ & $3.89 \mathrm{e}-12$ & $\star$ \\
ODA \& Foreign Aid & $-2.30 \mathrm{e}-11$ & $7.27 \mathrm{e}-12$ & $\star$ \\
Political Stabilityit-1 & .0490559 & .0244088 & $\star$ \\
Constant & -1.01714 & .0957538 & $\star \star \star$ \\
Prob. $>$ F & $<0.000$ & & \\
$R^{2}$ & 0.95 & & \\
Observations & 219 & & \\
\end{tabular}

Dependent variable: Government effectiveness ${ }^{31}$ - perceptions of the quality of policies and public services provided

Level of significance on a two-tailed test denoted by the following symbols:

NS- not significant, ${ }^{\wedge} p<0.10,{ }^{\star} p<0.05,{ }^{\star \star} p<0.01,{ }^{\star \star \star} p p<0.001$.

The hold out country is Afghanistan and the hold out year is 2004

knowledge and/or pressures and standards that overtime cause governments to improve their effectiveness. Since our hypothesis is to examine the latter possibility, we present the results without lagging FDI. A post estimation test with lagged FDI shows the results to be consistent, therefore, we interpret the findings in congruence with previous research that posits a causal relationship between foreign investment and government effectiveness (Kosack and Tobin, 2006; Luo and Tung, 2007; ${ }^{18}$ Busse and Gröning, 2009). Our results support that hypothesis although the relationship we observe here is at the 0.10 level, or at the $90 \%$ confidence level.

Our main hypothesis that government effectiveness is improved by information technology connectivity is also supported with respect to Internet subscriptions. However, we observe a negative relationship between increasing mobile phone usage and government effectiveness. Could our results be showing a precursor of the much currently discussed (mostly in the media and professional literature) deployment of mobile phone technology for recruitment and mobilization of organizations such as ISIS ${ }^{19}$ and Boko Haram? That would be an over-reaching interpretation for several reasons. One is that, although increasing, mobile phone technology and its marginal proliferation in the region did not significantly reach the majority of the populace, particularly in the early years of our time series. Castells et al. (2009) offer a thorough analysis of the reasons with detailed growth data for the Middle East. Among those reasons is the fact that the deployment of mobile phone technology is still subject to general infrastructure development, which MENA nations lack in comparative terms. We explain that platform as we analyze the relationship between our connectivity variables and foreign direct investment, offered in Table 3.

When it comes to the other two variables used as proxies for outside influence, imports and foreign aid, our results reveal a unique situation. Imports are the strongest predictor of increasing government effectiveness, while foreign aid has a negative effect. These results are consistent with a body of work on aid dependence and corruption that explain how ODA can have negative impacts on the development of government institutions that are effective and equitable (Alesina and Weder, 1999; Bräutigam and Knack, 2004; Knack, 2004; Sachs, 2005; Rajan and Subramanian, 2008; Deaton, 2010; Sachs, 2014). The main charges are that ODA leads to dependency, incentivizes corruption and rewards poor governance. On the heels of this 
body of research, the precarious situation in the MENA region, its reliance on aid, and the fact that ODA has grown significantly in the recent past ${ }^{20}$, our findings point to persistent problems of aid effectiveness.

With respect to political stability, the results suggest that increasing stability improves government effectiveness, which is to be expected except for the fact that we are examining a region in a time period that can hardly be described as stable. We do note that the scale anchors stability in the context of "absence of terrorism". So, in effect it is not a measure that reflects democratic mobilization such as the protests of the Arab Spring. It is a measure most directly linked to the threat of terrorism. The higher the score, the lower the threat. The relationship we observe is positive and statistically significant, confirming the logical expectation that governments are more effective when the threat of terrorism is low. We caution other researchers who employ the scale to be mindful of context. Pro-democracy demonstrations, uprisings, and general revolt are the opposite of political stability in definition. Do they increase the threat of terrorism? Future studies should address this question. In Table 2, we show the results when the score is employed as a dependent variable.

The results indicate once more the strong impact of imports and aid. Imports positively affect political stability while aid shows the strongest impact and the direction is negative. ${ }^{21}$ There is a large body of research on aid effectiveness that addresses the limitations of ODA policies. We feel there is little to its main findings that we can add, except the troubling causal relationships in our results. We urge scholars that focus on MENA governance to examine in depth why the problem is so persistent. Observing the raw numbers, we see that the wealthier MENA states not only receive aid, but they are also among the world's leading donors with Saudi Arabia, the United Arab Emirates ${ }^{22}$, Turkey and Kuwait earning praise for their generosity. For example, The Middle East Center at the London School of Economics and Political Science reports that Kuwait gives 2.7\% of its GDP in aid -twice the amount suggested by UN Official Development Assistance commitment. Most of it is regional and, according to articles 1 and 12 of its Constitution, is for programs devoted to Arabism and Islam in the region. ${ }^{23}$ According to our data, Turkey's aid receipts have grown from an average of 300 million in 2004 to approximately 3 billion by 2014 . According to the Middle East Institute, its role as an important regional donor has grown over the same period, reaching $\$ 3.3$ billion by $2015 .^{24}$

\begin{tabular}{|c|c|c|c|}
\hline Variables & Coefficient & Standard Error & Significance \\
\hline $\begin{array}{l}\text { Internet Subscribers } \\
\text { (per 100) }\end{array}$ & .0021373 & .0029859 & NS \\
\hline $\begin{array}{l}\text { Mobile Subscribers } \\
\text { (per 100) }\end{array}$ & -.0000297 & .0016241 & NS \\
\hline $\begin{array}{l}\text { Government } \\
\text { Effectiveness }_{\text {it-1 }}\end{array}$ & .0066453 & .085763 & NS \\
\hline FDI & $5.05 e-12$ & $8.08 \mathrm{e}-12$ & NS \\
\hline Imports & .0045616 & .0015841 & $\star \star$ \\
\hline ODA \& Foreign Aid & $-6.60 e-11$ & $1.44 \mathrm{e}-11$ & $\star \star \star ~$ \\
\hline Constant & -1.750457 & .1898091 & $\star \star \star \star ~$ \\
\hline Prob. $>\mathrm{F}$ & $<0.000$ & & \\
\hline R-squared & 0.92 & & \\
\hline Observations & 219 & & \\
\hline \multicolumn{4}{|c|}{$\begin{array}{l}\text { Dependent variable: Political stability and absence of violence and terrorism } \\
\text { government destabilization by violent means and/or unconstitutional political participation of } \\
\text { expression } \\
\text { Level of significance on a two-tailed test denoted by the following symbols: } \\
\text { NS-not significant, }{ }^{\prime} p<0.10,{ }^{\star} p<0.05,{ }^{* \star} p<0.01,{ }^{* \star \star} p<0.001 \text {. }\end{array}$} \\
\hline
\end{tabular}

The reports in the media of such rise assume a positive stance. Yet, our results suggest a relationship of dependence that is troubling and numbers that are rising exponentially. An in-depth analysis of the reasons is beyond the scope of this paper, but it should be addressed urgently and carefully.

In terms of improvements in governance, the result that imports are a positive factor merits some discussion. Our data use raw import numbers in billions of current U.S. dollars, but we also examined import numbers as percent of GDP, as reported by the World Bank. In the MENA region those percentages are large. The imports to GDP ratios of the poorer nations in the sample were high in the beginning of the time series, with Afghanistan, Djibouti, and the West Bank at around 80\%, but have notably decreased from year to year. On the other hand, the wealthier and more industrialized nations started off with lower ratios that steadily rose from 2004 to 2014. The Observatory of Economic Complexity's Media Lab at MIT, from which the raw import numbers are derived, offers a visualization tool which breaks down import percentages by sectors and products. We note a high concentration of the growth in telecommunication technology products. For example, in Iran in 2014, "telephones" were among the largest product lines at $1.8 \%$ of imports, on par with cars and car parts, most commodities and surpassing medications. In Jordan in 2014, telephones, computers and broadcasting equipment totalled more than $2 \%$ of imports, once again surpassing such essentials as medications and foodstuffs. The granulated analysis of this trade shift should be subject for further query, linking IT innovation and proliferation and the import dynamics in nations with underdeveloped local technological capabilities. Our data suggest that such growth has a positive impact on political stability and government effectiveness.

It is well accepted that government effectiveness creates outcomes. In the economic development literature on industrial upgrading of developing countries, one of the most often studied such outcome is the ability of nations to attract FDI (Globerman and Shapiro, 2002, 2003; Wint and Williams, 2002; Daud and Stein, 2007). On the basis of these findings, we test the effectiveness and stability measures as factors attractive to FDI. Table 3 shows the results when FDI is employed as the dependent variable.

To make sure we control for the most important elements that attract FDI, we include GNI per capita because of evidence ${ }^{25}$ that foreign investment increases in countries with large and growing

Table 3 | Fixed effects cross sectional time series regression analysis, FDI, 2004-2014

\begin{tabular}{|c|c|c|c|}
\hline Variables & Coefficient & Standard Error & Significance \\
\hline $\begin{array}{l}\text { Internet subscribers } \\
(\text { per 100) })_{\text {it-1 }}\end{array}$ & $-5.30 e+07$ & $2.25 e+07$ & * \\
\hline $\begin{array}{l}\text { Mobile subscribers } \\
(\text { per 100) })_{\text {it-1 }}\end{array}$ & $2.13 e+07$ & $1.14 e+07$ & $\hat{\imath}$ \\
\hline GNI per capita & -18716.75 & 78998.54 & NS \\
\hline \multicolumn{3}{|l|}{ effectiveness } & $\hat{\imath}$ \\
\hline Political stability & $-2.49 e+08$ & $7.68 e+08$ & NS \\
\hline ODA \& Foreign aid & .0081499 & .1441955 & NS \\
\hline Imports & -2592766 & $1.61 e+07$ & NS \\
\hline Constant & $3.00 e+08$ & $2.45 e+09$ & NS \\
\hline Prob. $>\mathrm{F}$ & $<0.000$ & & \\
\hline$R^{2}$ & 0.74 & & \\
\hline Observations & 219 & & \\
\hline \multicolumn{4}{|c|}{$\begin{array}{l}\text { Dependent variable: FDI-the overall balance of foreign assets to liabilities in a country } \\
\text { measured in current US dollars } \\
\text { Level of significance on a two-tailed test denoted by the following symbols: } \\
\text { NS - not significant, }{ }^{\wedge} p<0.10,{ }^{\star} p<0.05,{ }^{\star \star} p<0.01,{ }^{\star \star \star} p<0.001 \text {. }\end{array}$} \\
\hline
\end{tabular}


GNIs. We also lag both Internet Subscribers and Mobile Subscribers by one year because of possible endogeneity. In the MENA region, as Shirazi (2008) explains, FDI is used to develop the information technology sector. Significant amounts of FDI may be directed to each industry and therefore can cause Internet use and mobile subscriptions to increase. However, our results do not indicate that to be the case. We observe the opposite outcome -an increase in Internet users shows a significant negative impact on FDI. This result may seem counter intuitive, but it is an established dynamic in knowledge-intensive industrial sectors such as information and telecommunication technologies (ITC) that are not subject to diminishing returns to scale. In those sectors, there are high up-front production costs, but they decrease with time as output increases. Simply put, if we assume that in our region FDI was behind Internet and mobile industrial proliferation, a sizable investment in each sector would have been required at market entry. With time, increases in output, such as adding more Internet users, would not require significant additional investments. Firm-level research supports our assumption, showing that, at large, foreign firms champion ITC proliferation in MENA nations (Gelvanovska et al., 2014; Pick and Sarkar, 2015). Shirazi (2008) explains that the result is very high return on investment for Internet providers in the Middle East. However, we note a positive, but slight impact on FDI of mobile subscriptions. Mobile infrastructure is deployed much easier than web connectivity because of its lower dependence on laying broadband cable and higher reliance on tower technology. These features make it cheaper to deploy, and more readily available for consumers and as the works on smart phone usage in the Middle East note, it is more common for citizens to have smart phones than personal computers. The interpretation of our findings is that such improvements can attract FDI from both within and outside the telecommunications industry because of their pivotal role in business operations.

The results also suggest that improvements in government effectiveness can cause slight FDI growth, while lowering the risk of terrorism does not seem to matter to foreign investors. Further research should focus on this very important finding as it suggests a possible relationship between FDI sources that do not value stability or increasing economic partnerships in unstable nations such as Iran and Syria with investors from Russia and China, as reported during the Arab Spring ${ }^{26}$ and the ongoing civil war in Syria. ${ }^{27}$ For example, as U.S. sanctions on Iran were conditionally lifted in 2016, the New York Times ${ }^{28}$ offered a thorough analysis of Chinese investment in Iran before the end of sanctions, and how that investment serves as the foundational platform for future inflows.

\section{Conclusion and implications}

In this article, we suggest a way for expanding how scholars study soft power outcomes. We focus on vehicles, or channels, through which soft power messages travel. In our 2015 work $^{29}$ we first show that economic indicators can be employed, particularly those representing the spread of foreign assets into a country. In this paper we delve further into the nature and magnitude of such assets. We hypothesize that those foreign assets may be viable soft power channels precisely because of their foreignness. Foreign goods and services are promoted based on beneficial lifestyle changes and the literature on cultural conversion has found evidence that the promotion of foreign products depict foreign lifestyles that have led to increases in pro-Western attitudes and cultural change. However, our results indicate that the opposite may be happening if we focus on mobile technology-the very platform that most effectively increases connectivity to external ideas. We discover that in MENA nations mobile technology is not only imported, it holds a significant place in relations to other imports, particularly in the more impoverished nations in our sample. We find that in nations with the highest rates of mobile technology adoption, government effectiveness scores decreased. Is it a causal relationship? Future research must address this very important question. Are forces like ISIS mobilizing effectively because of mobile technologies? Is such mobilization reaching critical mass and actually causing a decrease in government effectiveness? Should the answer be "yes" then why are not antiISIS forces just as effective, including soft power initiatives? Are they not being deployed optimally via mobile platforms? There have been discussions arguing both points. Most notably the CNN exposes "Why Do They Hate Us" and "Why Do They Still Hate Us" offer some discussion on the link between technological innovation and the rise of the Islamic State, in particular. The question our data analysis highlights is: "Why aren't the soft power pro-Western messages (and their proliferation as our literature review tracks) a viable antidote?"

For answers, we urge scholars to focus on firm-level information technology commerce. We know that it is global firms that bring forth IT innovation. Yet, we could not find much $^{30}$ academic work that identifies which corporations shape local digital markets and define the commercialization of the MENA cyber space. The marketing platforms of those enterprises can be studied for their soft power aspects. It is also important to know who are the local merchants and what is their relationship to local governance and political forces. Understanding the connection can aid analysts of soft power and diplomacy at large identify factors that frustrate soft power effectiveness.

\section{Notes}

1 Available at: http://www.state.gov/documents/organization/207305.pdf

2 For a thorough discussion on the subject see Mickelson, Sig. (1983). America's Other Voice: The Story of Radio Free Europe and Radio Liberty. New York: Praeger

3 For a historic perspective in particular, see Allen (2015)

4 For the press briefing of the Department of State annoucning the SVI, go to: http:// iipdigital.usembassy.gov/st/english/texttrans/2003/01/20030116185938skaufman@ pd.state.gov0.3441126.html\#axzz2sJX0pV53

5 The report is available at: http://www.arabvoices.net/docs/2004_impressions_of_ america_poll.pdf

6 For analysis of the findings and a copy of the full report go to: http://www.pewglobal. org/2009/07/23/lessons-from-the-2009-global-attitudes-survey-transcript/

7 Report can be found at: http://www.pewglobal.org/files/2012/06/Pew-Global-Atti tudes-U.S.-Image-Report-FINAL-June-13-20123.pdf

8 Report can be found at: http://eca.state.gov/files/bureau/youth-exchange-and-studyyes-full-report-aug-2009.pdf

9 For a complete description of the methodology go to: http://info.worldbank.org/ governance/wgi/index.aspx\#doc-sources

10 Our model shares some of Busse and Hefeker's variables, but for years post their 1990-1999 time frame.

11 Although the relationship we discuss in our 2015 work on the link between foreign aid and increase in girls' access to education is important, it is outside the scope of this article.

12 Definition available at: http://info.worldbank.org/governance/wgi/index.aspx\#faq 13 Definition available at: http://info.worldbank.org/governance/wgi/index.aspx\#faq

14 The Iraqi Insurgency, Egyptian Revolution and Syrian Conflict all began in 2011.

15 Other sources include UNESCO, UNICEF, Trading Economics, Investment Map, the foreign affairs ministries of individual nations and the United Nation's Conference on Trade and Development databases.

16 The data at MIT are complied from several sources disclosed here: http://atlas.media. mit.edu/en/resources/data/

17 We fix on individual country and year to best control for unobserved heterogeneity among the nations in the sample

18 Busse and Gröning (2009) explain that foreign investors lobby for improvements in governance

19 Groll, Elias. (December 8th, 2015). "Welcome to the Future of War: ISIS Has a SmartPhone App". Foreign Policy

20 For example, according to the World Bank, in 2013, members of the Organization for Economic Co-operation and Development's (OECD) Development Assistance Committee (DAC) provided $\$ 135$ billion in ODA, an increase from the $\$ 71$ billion given in 1997 
21 Also see: Swanson, Ana. (October 13th, 2015). "Why trying to help poor countries might actually hurt them”. The Washington Post. https://www.washingtonpost.com/ news/wonk/wp/2015/10/13/why-trying-to-help-poor-countries-might-actually-hurtthem/

22 See: Dali-Balta, Soraya. (11 March 2015). "The United Arab Emirates leads countries of the world in foreign humanitarian aid." ifcr.org available at: http://www.ifrc.org/ en/news-and-media/news-stories/middle-east-and-north-africa/united-arab-emi rates/the-united-arab-emirates-leads-countries-of-the-world-in-foreign-humanitar ian-aid-68193/

23 See: Al-Ojayan, Hessah. (November 13th, 2015). "Kuwait's Economic 'Toolkit': Foreign Aid \& the Kuwait Investment Authority”. available at: http://blogs.lse.ac.uk/ mec/2015/11/13/kuwaits-economic-toolkit-foreign-aid-the-kuwait-investmentauthority/

24 See: Tol, Gönül. (30 September 2015). “The Rise of Turkish Foreign Aid.” mei.edu, available at: http://www.mei.edu/content/article/rise-turkish-foreign-aid

25 For a thorough discussion see Blonigen, Bruce and Jeremy Piger. (2011). "Determinants of Foreign Direct Investment." Working Paper No. w16704. National Bureau of Economic Research available at: http://www.nber.org/papers/w16704

26 For a thorough discussion the Russo-Arab relationships during the Arab Spring see Katz, Mark. (2012). "Russia and the Arab Spring." The Middle East Institute, Washington DC. available at: http://www.mei.edu/content/russia-and-arab-springFor a synopsis of the history and economic interests of China in the Middle East see Pollack, Jonathan. (2011). "Unease From Afar", Brookings Institute, Washington, DC. available at: http://www.brookings.edu/research/articles/2011/11/18-arab-awa kening-china-pollack

27 See: O’Tool, James. (10 February 2012). "Billions at State as Russia Backs Syria." CNNMoney.com available at: http://money.cnn.com/2012/02/09/news/international/ russia syria/

28 See: Erdbrink, Thomas. (January 24th, 2016). "China Deepens Its Footprint in Iran After Lifting of Sanctions". The New York Times

29 See: Nikolay Anguelov. (2015). Alternatives to Sanctions. In Economic Sanctions vs. Soft Power (pp. 71-110). Palgrave Macmillan US.

30 For some examples see: (Anguelov, 2015), Chapters 5 and 6

31 The methodology of calculation is explained at: http://info.worldbank.org/govern ance/wgi/index.aspx\#doc

32 Explanation of the methodology behind building the score can be found at: http:// info.worldbank.org/governance/wgi/index.aspx\#doc

\section{References}

Agar J (2013) Constant Touch: A Global History of The Mobile Phone. Icon Books: London.

Ahmed AD, Cheng E and Messinis G (2011) The role of exports, FDI and imports in development: evidence from Sub-Saharan African countries. Applied Economics; 43 (26): 3719-3731.

Aker J and Mbiti I (2010) Mobile phones and economic development in Africa. Center for Global Development Working Paper 211, Washington DC, London.

Alesina A and Weder B (1999) Do corrupt governments receive less foreign aid? Working Paper \#7108. National Bureau of Economic Research, Washington DC.

Allen L (2015) The Influence of Information and Communication Technologies on Societies and their Cultures: A Historical Perspective. In: Thomas K (ed). Handbook of Research on Sustainable Development and Economics; IGI Global: Hershey, PA, pp 360-383.

Anguelov N (2015) Economic Sanctions Vs. Soft Power: Lessons from North Korea, Myanmar, and the Middle East; Springer: New York.

Assaad R and Roudi-Fahimi F (2007) Youth in the Middle East and North Africa: Demographic Opportunity or Challenge?. Population Reference Bureau: Washington DC.

Atkinson C (2010) Does soft power matter? A comparative analysis of student exchange programs 1980-2006. Foreign Policy Analysis; 6 (1): 1-22.

Baltagi BH (2008) Forecasting with panel data. Journal of Forecasting; 27 (2): $153-173$.

Bjørnskov C (2010) Do elites benefit from democracy and foreign aid in developing countries? Journal of Development Economics; 92 (2): 115-124.

Blanton SL and Blanton RG (2007) What attracts foreign investors? An examination of human rights and foreign direct investment. Journal of Politics; 69 (1): 143-155.

Bräutigam DA and Knack S (2004) Foreign aid, institutions, and governance in Sub-Saharan Africa. Economic Development and Cultural Change; 52 (2): 255-285.

Brown GK, Langer A and Stewart F (2008) A Typology of Post-Conflict Environments: An Overview. Centre for Research on Inequality, Human Security and Ethnicity. University of Oxford Press: Oxford.

Busse M and Hefeker C (2007) Political risk, institutions and foreign direct investment. European Journal of Political Economy; 23 (2): 397-415.

Busse M and Gröning S (2009) Does foreign aid improve governance? Economics Letters; 104 (2): 76-78.
Castells M, Fernandez-Ardevol M, Qiu JL and Sey A (2009) Mobile Communication and Society: A Global Perspective. MIT Press: Boston, MA.

Chan KK and Gemayel ER (2004) Risk instability and the pattern of foreign direct investment in the Middle East and North Africa region. International Monetary Fund Working Paper 04/139, http://papers.ssrn.com/sol3/papers.cfm?abstract_ id $=878964$.

Daniele V and Marani U (2006) Do institutions matter for FDI? A comparative analysis for the MENA countries. MPRA Working Paper 2426, Munich University Library, Munich, Germany.

Daude C and Stein E (2007) The quality of institutions and foreign direct investment. Economics \& Politics; 19 (3): 317-344.

Davison RH (1960) Where is the Middle East? Foreign Affairs; 38 (4): 665-675.

Deaton A (2010) Instruments, randomization, and learning about development. Journal of Economic Literature; 48 (2): 424-455.

De Mooij M (2013) Global marketing and advertising: Understanding cultural paradoxes; Sage Publications: Los Angeles, CA.

Department of State Bureau of Educational and Cultural Affairs. (2009) "Evaluation of the Youth Exchange and Study Program", Final Report \# 20037, Office of Policy and Evaluation, Washington DC, available at: https:// eca.state.gov/files/bureau/youth-exchange-and-study-yes-full-report-aug-2009. pdf.

Dunn A (2011) Unplugging a nation: state media strategy during Egypt's January 25 Uprising. Fletcher Forum Of World Affairs; 35 (2): 15-24.

Elasmar MG (ed) (2014) The impact of international television: A paradigm shift Routledge: London.

El-Nawawy M (2006) US public diplomacy in the Arab world the news credibility of Radio Sawa and Television Alhurra in five countries. Global Media and Communication; 2 (2): 183-203.

Fan Y (2008) Soft power: Power of attraction or confusion? Place Branding and Public Diplomacy; 4 (2): 147-158.

Fullerton JA and Kendrick A (2006) Advertising's War on Terrorism: The Story of the US State Department's Shared Values Initiative. Marquette Books: Spokane, Washington.

Gani A (2007) Governance and foreign direct investment links: Evidence from panel data estimations. Applied Economics Letters; 14 (10): 753-756.

Gelvanovska N, Rogy M and Rossotto CM (2014) Broadband Networks in the Middle East and North Africa: Accelerating High-speed Internet Access. World Bank Publications: Washington DC.

Globerman S and Shapiro D (2002) Global foreign direct investment flows: The role of governance infrastructure. World Development; 30 (11): 1899-1919.

Globerman S and Shapiro D (2003) Governance infrastructure and US foreign direct investment. Journal of International Business Studies; 34 (1): 19-39.

Golan G and Yang Sung-Un (2013) Diplomat in chief? Assessing the influence of presidential evaluations on public diplomacy outcomes among foreign publics. American Behavioral Scientist; 57 (9): 1277-1292.

Goldsmith BE and Horiuchi Y (2012) In search of soft power: does foreign public opinion matter for US foreign policy? World Politics; 64 (3): 555-585.

Greene WH (2008) Econometric Analysis, 6th edn. Pearson/Prentice Hall: Upper Saddle River, NJ.

Hayden C (2012) The Rhetoric of Soft Power: Public Diplomacy In Global Contexts. Lexington Books: Lanham, MD.

Husted BW and Instituto Tecnologico y de Estudios (1999) Wealth, culture, and corruption. Journal of International Business Studies; 30 (2): 339-359.

Jiang J and Wei R (2012) Influences of culture and market convergence on the international advertising strategies of multinational corporations in North America, Europe and Asia. International Marketing Review; 29 (6): 597-622.

Jreisat JE (2006) The Arab world reform or stalemate. Journal of Asian and African Studies; 41 (5-6): 411-437.

Kamalipour YR and Snow N (eds) (2004) War, Media, and Propaganda: A Global Perspective. Rowman \& Littlefield: Lanham, MD.

Kaufmann D, Kraay A and Zoido-Lobatón AP (1999) Aggregating Governance Indicators Vol. 2195. World Bank Publications: Washiongton DC.

Khamis S and Vaughn K (2011) Cyberactivism in the Egyptian revolution: How civic engagement and citizen journalism tilted the balance. Arab Media and Society; 13 (3): 1-37.

Knack S (2004) Does foreign aid promote democracy? International Studies Quarterly; 48 (1): 251-266.

Kosack S and Tobin J (2006) Funding self-sustaining development: The role of aid, FDI and government in economic success. International Organizations; 60 (1): 205-243.

Kroenig M, McAdam M and Weber S (2010) Taking soft power seriously. Comparative Strategy; 29 (5): 412-431.

Lam PE (2007) Japan's quest for "soft power": Attraction and limitation. East Asia; 24 (4): 349-363.

Lee SY and Whitford AB (2009) Government effectiveness in comparative perspective. Journal of Comparative Policy Analysis; 11 (2): 249-281. 
Little D (2008) American Orientalism: The United States and the Middle East Since 1945. UNC Press: Chapel Hill, NC.

Luo Y and Tung RL (2007) International expansion of emerging market enterprises: A springboard perspective. Journal of International Business Studies; 38 (4): 481-498.

Mattern JB (2005) Why soft power isn't so soft: representational force and the sociolinguistic construction of attraction in world politics. Millennium Journal of International Studies; 33 (3): 583-612.

McAlister M (2005) Epic Encounters: Culture, Media, and US Interests in the Middle East since 1945. University of California Press: Berkeley, CA.

Melissen J and Lee SJ (eds). (2011) Public Diplomacy and Soft Power in East Asia. Palgrave Macmillan: New York.

Miller B and Thorr JD (2003) Developing Nations. Greenhaven Press: Farmington Hills, MI.

Newsom VA and Lengel L (2012) Arab women, social media, and the arab spring: Applying the framework of digital reflexivity to analyze gender and online activism. Journal of International Women's Studies; 13 (5): 30-45.

Nincic M and Russett B (1979) The effect of similarity and interest on attitudes toward foreign countries. Public Opinion Quarterly; 43 (1): 68-78.

Nisbet EC, Nisbet MC, Scheufele DA and Shanahan JE (2004) Public diplomacy, television news, and Muslim opinion. The Harvard International Journal of Press/Politics; 9 (2): 11-37.

Nye J (2002) Hard and soft power in a global information age. In: Leonard M (ed). Reordering the World. Foreign Policy Centre (FPC): London.

Nye J (2004) Soft power and higher education. In: Internet and the University Forum, https://net.educause.edu/ir/library/pdf/ffpiu043.pdf, accessed 28 February 2017.

Nye J (2010) The future of soft power in US foreign policy. In: Parmar I and Cox M (eds). Soft Power And US Foreign Policy: Theoretical, Historical And Contemporary Perspectives. Routledge: New York.

Nye JS (1990) Soft power. Foreign Policy; 80 (Autumn): 153-171.

Nye JS (2008) Public diplomacy and soft power. The Annals of The American Academy of Political And Social Science; 616 (1): 94-109.

Pamment J (2015) Media influence, ontological transformation, and social change: conceptual overlaps between development communication and public diplomacy. Communication Theory; 25 (2): 188-207.

Pick JB and Sarkar A (2015) The Global Digital Divides. Springer: Berlin, Heidelberg, Germany.

Puddington A (2003) Broadcasting Freedom: The Cold War Triumph of Radio Free Europe and Radio Liberty. University of Kentucky Press: Lexington, Kentucky.

Radelet S (2003) Bush and foreign aid. Foreign Affairs; 84 (5): 104-117.

Rajan R and Subramanian A (2008) Aid and growth: What does the crosscountry evidence really show? The Review of economics and Statistics; 90 (4): 643-665

Roselle L, Miskimmon A and O'Loughlin B (2014) Strategic narrative: A new means to understand soft power. Media, War \& Conflict; 7 (1): 70-84.

Rugh WA (2006) American Encounters With Arabs: The "Soft Power" of US Public Diplomacy In The Middle East. Greenwood Publishing Group: Westport, CA

Sachs JD (2005) The End of Poverty. Penguin Group: New York.

Sachs JD (2014) The Age of Sustainable Development. Columbia University Press: New York

Savun B and Tirone DC (2011) Foreign aid, democratization, and civil conflict: how does democracy aid affect civil conflict? American Journal of Political Science; 55 (2): 233-246.

Schneider CP (2003) Diplomacy that works: "Best practices" in cultural diplomacy. Center For Arts and Culture (Cultural Diplomacy Research Series), http:// intranet.americansforthearts.org/sites/default/files/pdf/2013/by_program/afta_ pubs/cac_pubs/Schneider.pdf.

Scott JM and Steele CA (2011) Sponsoring democracy: The United States and democracy aid to the developing world, 1988-20011. International Studies Quarterly; 55 (1): 47-69.

Shirazi F (2008) The contribution of ICT to freedom and democracy: An empirical analysis of archival data on the Middle East. The Electronic Journal of Information Systems in Developing Countries; 35 (6): 1-24.

Smith PH (2007) Politics and diplomacy: The hard road back to soft power. Georgetown Journal of International Affairs; 8 (1): 1-9.

Snow N (2008) International exchanges and the US image. The Annals of The American Academy of Political And Social Science; 616 (1): 198-222.

Takeyh R and Gvosdev N (2002) Do terrorist networks need a home? Washington Quarterly; 25 (3): 97-108.

Taylor PM (1992) War and the media: Propaganda and persuasion in the Gulf War. Manchester University Press: Manchester, UK.

Tillman S (1982) The United States In The Middle East, Interests And Obstacles Indiana University Press: Bloomington, IN.

Tujan A, Gaughran A and Mollett H (2004) Development and the 'global war on terror'. Race \& Class; 46 (1): 53-74.

Van de Walle N (2012) Foreign aid in dangerous places: The donors and Mali's democracy. WIDER Working Paper 2012/61, Helsinki, Finland.

Verčič D (2008) Public relations and power: How hard is soft power? In: Van Zerfaß A, Ruler AA and Sriramesh K (eds). Public Relations Research: European and International Perspectives and Innovations. VS Verlag für Sozialwissenschaften: Wiesbaden, Germany.

Wint AG and Williams DA (2002) Attracting FDI to developing countries: A changing role for government? International Journal of Public Sector Management; 15 (5): 361-374.

Wunderle W and Briere A (2007) Uncertain future: A strategic review of the Middle East and implications for the United States. Comparative Strategy; 26 (3): 205-214.

Yun S-H and Kim J-N (2008) Soft power: from ethnic attraction to national attraction in sociological globalism. International Journal of Intercultural Relations; 32 (6): 565-577.

\section{Data availability}

Data sharing not applicable to this article as no datasets were analysed or generated.

\section{Additional information}

Competing interests: The authors declare that they have no competing financial interests.

Reprints and permission information is available at http://www.palgrave-journals.com/ pal/authors/rights_and_permissions.html

How to cite this article: Anguelov N and Kaschel T (2017) Toward quantifying soft power: the impact of the proliferation of information technology on governance in the Middle East. Palgrave Communications. 3:17016 doi: 10.1057/palcomms.2017.16.

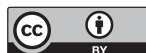

This work is licensed under a Creative Commons Attribution 4.0 International License. The images or other third party material in this article are included in the article's Creative Commons license, unless indicated otherwise in the credit line; if the material is not included under the Creative Commons license, users will need to obtain permission from the license holder to reproduce the material. To view a copy of this license, visit http://creativecommons.org/licenses/by/4.0/ 